\title{
THE STRUGGLE FOR FEDERAL FOOD AND DRUGS LEGISLATION
}

\author{
C. C. RrGIER*
}

In a simple agricultural society the problem of food supply devolves upon every family. Nearly every family produces its own supply, and those who do not produce it themselves obtain it from their neighbors or in the local market. The effects of neglect or carelessness in the matter of sanitation fall upon the producers themselves.

This is different in an industrial society. There a large proportion of the population is entirely dependent upon the general market. People buy their food at the stores, often chain-stores, which have imported it from distant places, much of it in cans or packages. Usually only a small part of the food which is consumed in any community has been produced in that locality. Much of it has come from other states and countries. And what is true in this respect of food is also true of drugs, narcotics, and liquors.

Under the police power a state may protect its citizens in health, welfare, and morals; but hcw can a state protect the health of its citizens effectively when so much of what they consume comes from the outside? (Then, too, it must be remembered that the exercise of jurisdiction by a state over goods from without its borders is subject always to the risk that the Supreme Court will regard its action as an "unreasonable interference" with interstate commerce.)

The transition from an agricultural to an industrial society is a gradual process. In the United States it came about during the second half of the nineteenth century. The federal law-makers, however, were not willing to face this fact squarely-as far as the food situation was concerned-until the twentieth century was well on the way. To describe briefly the movements, forces, and events which brought about this change in legislation is the aim of this article.

The first step in the struggle to guarantee pure food and drugs by law was taken in $185^{\circ}$. In that year a federal statute was passed which provided for the classification of tea and for the exclusion of certain kinds. ${ }^{1}$ Between January 20, I879, and June 30, I906, when the Food and Drugs Act was passed, Igo measures were presented in Congress which were designed in some way to protect the consumer of

- A.B., (I9I I), A.M., (I912) State Univcrsity of Kansas, Ph.D., (1922) University of Chicago and State University of Iowa. Teacher in several colleges. Fiead of the Department of History and Political Science of New River State College, Montgomery, West Virginia. Author of The Era of the Mtrckrakers (1932).

${ }^{\mathrm{I}}$ WILEY, AN AUTOSIOGRAPHIY (1930) 198. 
food and drugs. "Of these, eight became law, six passed the House but not the Senate, three passed the Senate but not the House, twenty-three were reported favorably from the committee to which they had been referred, nine were reported back adversely, and I4I were never heard of after their introduction."

Professor Thomas A. Bailey, in an illuminative article on "Congressional Opposition to Pure Food Legislation, I879-1906," claims that it was understood from the beginning that a sweeping pure-food law could not be obtained all at once; that the movement was a gradual evolution from specific laws on definite articles, such as those on glucose, cheese, meat, lard, butter, oleomargarine, baking powder, tea, drugs, canned fish, to the general law of 1906; and that "it was comparatively easy to pass a measure governing the importation of foreign goods, less easy to regulate exported goods, less easy to improve food conditions in the District of Columbia, and exceedingly difficult to prohibit adulterated foods in interstate commerce."3

At first there was very little interest in this sort of legislation. It was regarded as the work of cranks and reformers. In 1884 a resolution was introduced in the House authorizing an investigation of adulterated food and drugs by the Committee on Public Health, but it received only fourteen favorable votes. Two years later a tax was placed on oleomargarine, to which the South was almost solidly opposed, for cotton-seed oil went into the manufacture of this product. Between 1887 and I892 hundreds of petitions were sent to Congress protesting against the manufacture of compound lard. This precipitated a contest between the cotton-seed oil producing states and the hog raising states. Congress would not act, and so the agitation collapsed. In 1890 a law was passed which provided for the inspection of meat for export and for the prohibition of importation of adulterated food and drinks. This was largely caused by the refusal on the part of Germany and France to receive diseased meat from this country. In the 5Ist Congress (1889-9r) Senator Paddock of Nebraska sponsored the first general pure food bill. He tried, vainly, on four separate occasions to secure action on the bill. Always there were appropriation bills in the way. In the next Congress he succeeded in inducing the Senate to pass such a bill, only to have the House give it a lingering death.

There seemed to be an understanding between the two houses that when one passed a bill to repress food adulteration the other would see to it that it was buried. ${ }^{4}$ In the later stages of the struggle, when it had become dangerous to oppose such measures openly, the proponents of pure food bills encountered great difficulty in getting the bills called up at all. Excuses were always found. Among the most common were: more pressing legislation, agreement in principle but opposition to construction, the desirability of letting the states handle their own problems in their own way, and the prevention of hasty legislation. ${ }^{5}$

The opposition to pure food legislation came chiefly from three classes. First,

'Bailey, Congressional Opposition to Pure Food Legislation (1930) 36 AM. J. Soc. 52.

Id.

"WILEY, op. cit. supra note I, at 202.

${ }^{B}$ Bailey, supra note 2, at 58 . 
there were those who objected on constitutional grounds. They did not wish to have the federal government extend its police power into the states. This opposition came largely from southern Democrats. Secondly, there were many who did not realize the seriousness of the problem. And finally, there were some who were personally interested in the perpetuation of frauds that would be illegal under a pure food statute. $^{6}$ The objection from the first two groups almost disappeared as the issue became clearer and public opinion more insistent, but the third class fought to the bitter end, although mostly under cover. Many of the congressmen feared to oppose the powerful business interests, for on big business most of the Republican senators and House members and practically all the more powerful ones, depended for re-election. ${ }^{\top}$

In the $57^{\text {th }}$ Congress (I90I-Ig03) and the $5^{8 \text { th }}$ (Ig03-Ig05) pure food and drugs bills were pressed with great vigor. In the House, Hepburn of Iowa was in charge, and Mann of Illinois very ably supported him. They were able to induce the House to pass the measure in each Congress; in the latter, by a vote of 201 to 68 . In the Senate, where the special interests were more firmly intrenched, it was more difficult. Here McCumber of North Dakota and Heyburn of Idaho were the chief advocates. They experienced great difficulty in getting the measure called up. When on February 25 , r903, a vote was taken to take up the bill, it was voted down 32 to 28 . Two years later it came to a debate, but no vote. Among those who raised objections were Aldrich of Rhode Island, Lodge of Massachusetts, Hale of Maine, Kean of New Jersey, Frye of Maine, Foraker of Ohio,. Platt of Connecticut, Spooner of Wisconsin, Hanna of Ohio, Cullum of Illinois, and Gallinger of New Hampshire-all Republicans.

Before Congress could be induced to act, it was necessary for public opinion to assert itself more vigorously, and that finally came about in no uncertain terms. As in many other matters, the legislation in favor of pure food was the result of a long process of education and agitation.

The resentment began with the farmers. ${ }^{8}$ They objected to the adulteration of milk, butter, lard, and other food products. They established state departments of agriculture, and provided themselves with state chemists whose duty was to analyse foods in order to detect imitations and adulterations. This led to an interest in the whole problem of sanitation and to food legislation. By I906 practically all the states had pure food laws. In 1898 the National Association of State Dairy and Food Departments was organized, and this association held annual meetings. It was soon apparent that only a national law would be adequate. The states, acting separately, could not protect themselves against interstate commerce, and by establishing different standards, they made it very difficult for the manufacturer to meet them all. The more reputable manufacturers of food products were not slow to appreciate that a federal law would be to their interest, but, as long as their competitors were

\footnotetext{
'Id. at 64.

' 2 SULLIVAN, OUR TIMEs (1929) 526.

${ }^{8} I d$. at 516 .
} 
allowed to imitate the goods of others and to adulterate and misbrand their own, they found themselves in a difficult position.

In the long crusade for pure food and drugs, the outstanding figure was Dr. Harvey W. Wiley. He was "a very mountain among men, a lion among fighters." At the same time he was a "keen student of human nature" and a "prince of good fellows." ${ }^{10}$ Not only was he an efficient scientist and investigator but also an effective writer and speaker. After a short but brilliant career as a chemist in Indiana, particularly at Purdue University, he was appointed Chief Chemist in the Department of Agriculture. This position he held from 1883 to I912. When Congress created the Bureau of Chemistry in the Department of Agriculture, he was made the chief of the new bureau.

When he entered upon his government duties he found much work to be done. After years of unrelenting activity in behalf of unadulterated food, he published his Bulletin No. 13, Bureau of Chemistry. This covered practically all classes of human food, and did much to create interest in the subject. Other reports, books, and articles followed from his prolific pen. In I902 he organized what came to be known as "Doctor Wiley's poison squad." This was an attempt to test the effect of commonly used food preservatives on the health of certain young men of the Department of Agriculture. These experiments were carried on for five years and proved conclusively that such preservatives are harmful to health. ${ }^{11}$ The press carried the reports of these investigations all over the world.

That his official position was not free from anxiety and interference may be inferred from what he says about the man who was his superior for fifteen years, Secretary of Agriculture James Wilson (I897-rgr3). Mr. Wilson, he wrote in later years, "had the greatest capacity of any person I ever knew to take the wrong side of public questions, especially those relating to health through diet."12 It was fortunate for Wiley, however, that he had good friends on the House Committee on Agriculture. These saw to it that the appropriations for the Bureau of Chemistry were not cut off.

About the time when Wiley organized his poison squad, the so-called muckrakers appeared upon the scene. They ruthlessly exposed a great variety of corruption and fraud, including all those interests which opposed the passage of a pure food and drugs act. Among these may be mentioned all those who were preserving foods by means of chemicals; the manufacturers of articles which were used in the adulteration of food and drugs; the "rectifiers," or producers of fraudulent whisky out of alcohol, colors, and flavors; the patent-medicine manufacturers; and the dishonest misbranders and mislabelers of food and drug products. Long before the era of the muckrakers had come to a close, the Food and Drugs Act of 1906 was safely on the statute books.

${ }^{\circ} I d$. at 520.

| ${ }^{10}$ Bigelow, Obituary-Harvey Washington Wiley (1930) 72 ScIENcE, 311, 312.

"11 WILEY, op. cit. supra note $\mathrm{r}$, at 215-220. ${ }_{12}$ Id. at rgo. 
The Ladies Home Journal and Collier's Weekly waged a determined campaign against the patent medicine fraud. Edward Bok and Mark Sullivan wrote for the former, and Samuel Hopkins Adams for the latter. Adams was easily the outstanding muckraker in this field. ${ }^{13}$ In 1905 and 1906 he wrote twelve articles under the general title "The Great American Fraud." Of these seven appeared before the act of $x 906$ was passed. He compared the chemical analyses with the curative claims of scores of patent medicines. Many of these contained alcohol, opium, or cocaine as the chief element. "Liquozone," he claimed, was composed of nine-tenths of a per cent of sulphuric acid, three-tenths of a per cent of sulphurous acid, and nearly ninety-nine per cent of water. And this was advertized to cure thirty-seven varieties of diseases. ${ }^{14}$ "Peruna" contained twenty-eight per cent of alcohol and often led to tuberculosis and drunkenness. It cost eight and a half cents to produce and sold for a dollar. ${ }^{15}$

Years later he described the conditions which prevailed before the passage of the act of Igo6 in these words: "Floods of potions, avalanches of pills and powders, had been pouring out from the various nostrum shops, without let or hindrance, to overflow the land. Seventy-five million dollars a year is a moderate estimate of the volume of business done by pseudo-medical preparations which 'eradicated' asthma with sugar and water, 'soothed' babies with concealed and deadly opiates, 'relieved' headaches through the agency of dangerous, heart-impairing, coal-tar drugs, 'dispelled' catarrh by cocaine mixture, enticing to a habit worse than death's very self, and 'cured' tuberculosis, cancer, and Bright's disease with disguised and flavored whiskies and gins." 16

The patent medicine interests were organized under the name "The Proprietary Association of America." It wielded a tremendous influence over the press through its advertisements. Wiley estimated that the newspapers and periodicals received $\$ x 00,000,000$ a year from advertising patent medicines. ${ }^{17}$ Collier's exposed their methods of muzzling the press. In order to prevent adverse legislation, President F. J. Cheney of the Association inserted in his advertising contracts with some 15,000 newspapers this clause: "It is mutually agreed that this contract is void if any law is passed in your state prohibiting the manufacture or sale of proprietary medicines."18 Others made the contracts even stronger. Few publishers would jeopardize their income from this source.

Scores of articles appeared in 1905 and $x 906$ which dealt with the patent medicine evil and the adulteration of food. Even Senator McCumber of North Dakota had an article in the Independent which was entitled "The Alarming Adulteration of Food and Drugs." In it he presented many facts which Professor E. F. Ladd, the Food Commissioner of his own state, had discovered. Ladd had never yet found a can

\footnotetext{
${ }^{13}$ Adams, as well as Wiley, was in close contact with congressional leaders during the final stages of the legislation for pure food and drugs.

1s Adams, Liquozone, Collier's, Nov. 18, 1905. ${ }^{15}$ Collier's, Oct. 28, 1905.

${ }^{19}$ Adams, The Fraud Medicines Own $U_{p}$, Collier's, Jan. 20, IgI2.

${ }^{17}$ WILEY, op. cit. stipra note I, at 208 . ${ }^{19}$ CollIER's, Nov. 4, I905.
} 
of potted chicken or potted turkey in North Dakota which contained chicken or turkey in determinable quantities. Of the local markets of his state, ninety per cent used chemical preservatives. The amount of borax or boracic acid which was used in sausages and hamburger steak ranged from twenty to forty-five grains per pound though the daily medical dose was only from five to nine grains. Nearly every imported ham contained borax. Boracic acid or borates were common ingredients of dried beef, smoked meats, canned bacon, and canned chipped beef. Ninety per cent of the so-called French peas were found to contain copper salts, and some contained aluminum salts in addition. Only one kind of catsup was free from chemical preservatives and coal tar coloring matters. About seventy per cent of cocoas and chocolates were adulterated, and glucose served a great variety of purposes. More than ten times the amount of Vermont maple syrup was sold every year than that state could produce. A large proportion of ground spices were imitations. Jellies, wines, and other liquors were made from cheap substances and then doctored up. Butter was a mixture of butter and deodorized lard. Ice cream contained no cream, only condensed milk and neutral lard. Cider vinegar usually contained no apple juice. Drugs were adulterated and misbranded in a similar fashion, often with deplorable consequences. ${ }^{19}$

Walter Lippmann claimed that a vivid description of food conditions would reveal revolting conditions, "Milk would curdle the blood, bread and butter would raise a scandal, candy - the volume would have to be suppressed. ${ }^{20}$ Jelly, stated another writer, was made out of apple cores, apple parings, and cheap apples. It was put into a large tank. As orders were received for various kinds of jellies, they were all filled from this same tank. Color and flavor were added as the demand required."2 The same practice was followed by the liquor dealers, as was revealed in the congressional debates. $^{22}$

The meat industry, too, was under attack. Beginning with February, 1905, Charles Edward Russell ran eight articles in Everybody's under the imposing title "The Greatest Trust In the World." He began the series with this statement: "In the free republic of the United States of America is a power greater than the government, greater than the courts or judges, greater than legislatures, superior to and independent of all authority of state and nation." No king or emperor or irresponsible oligarch, he went on to say, had ever wielded such power. It existed and proceeded in defiance of law. It, the Beef Trust, like the Standard Oil Trust, rested solely and squarely upon railroad rebates. These rebates had been received from all the railroads in spite of the Interstate Commerce Act. For 1905, Mr. Russell estimated, these rebates would probably amount to $\$ 25,000,000$. Although the rebates were in this case called "private car charges," the effects were the same. Through

\footnotetext{
${ }^{10}$ McCumber, The Alarming Adulteration of Food and Drugs, INDEPENDENT, Jan. 5, xg05.

${ }^{2}$ LippMann, DRIFT and Mastery (I914) 7.

${ }^{2}$ Lowry, The Senate Plot Against Pure Food, Worrd's Work, May, 1905.

240 CoNG. REC. I2I8 (I906).
} 
perfection of organization this trust had managed to increase the retail prices of meat in spite of the fact that the value of beef cattle in the United States had declined by $\$ 163,000,000$ in the three years ending January $I, 1905$.

Collier's Weekly also participated in this controversy. It commented on the damaging charges against the Chicago slaughterhouses which the English periodical, Lancet, made early in the same year. The Lancet articles were also an indictment of the government meat inspection service. And the denial of the charges on the part of the packers afforded Upton Sinclair an opportunity to write some scathing articles on the subject. ${ }^{23}$

The most sensational piece of literature concerning this matter, however, was not so much the product of typical muckraking as of fictional propaganda. After having spent seven weeks in "Packingtown" where he talked with workingmen, bosses, superintendents, night-watchmen, saloon-keepers, politicians, clergymen, and settlement-workers, Upton Sinclair wrote his famous novel, The Jungle. ${ }^{24}$ In it he told of the tragedies which befell a Lithuanian peasant while working in the Chicago meat-packing establishments. The book was meant to be propaganda for socialism, but what the public noted most were the bits of information which it gave about the unsanitary conditions which prevailed in the packing houses and the unclean meat that was sold to the public. Sinclair described how diseased cattle were butchered, marked by the government inspectors, thrown into dumps, loaded on carts and wheeled back again and mingled with other carcasses and treated and sold as clean meat. Animals that had died on the trains in transit were unloaded in the stockyards at night and treated as pure meat. Some of the descriptions of the filth and dirt that prevailed in the packing houses were utterly revolting. It is no wonder that many people lost temporarily their appetite for meat. The author said later he aimed at the public's heart and by accident hit it in the stomach. The Jungle was the best selling book for a year in the United States, Great Britain and her colonies. It was translated into seventeen languages, and by 1922 about 150,000 copies of it had been sold. ${ }^{25}$

The women, too, had a share in this campaign of education and agitation. The General Federation of Women's Clubs organized a Pure Food Committee in Ig04. This committee wrote some two thousand letters, sent circulars to every state, and tried by letters, talks, exhibits, and literature to arouse interest in the subject. It memorialized the President, the Secretary of Agriculture, the Senate and the House of Representatives, and kept up a newspaper warfare. ${ }^{26}$ It has been said that the women did more in this crusade without votes than they have done since Igrg with votes. ${ }^{27}$

"Sinclair, Is Chicago Meat Clean? CoLlier's, April 22, I905; Stockyard Secrets, Collier's, March 24, 1906; The Condemned-Meat Industry, Everubody's, May, Igo6.

"Sinclair, What Life Meant to Me, 4 I Cosmopoliran, 591-595.

${ }^{25}$ So stated in a personal letter to the writer from Upton Sinclair, June 30, 1922.

${ }^{*}$ Report of the Pure Food Committee of the General Federation of Women's Clubs (Ig06) 28 ANN. AM. ACad. OF PoL. AND Soc. ScI. 296.

${ }^{27}$ Sullivan, op. cit. supra note 7 , at 522 . 
After all this clamor-or rather, while the clamor was going on-Congress could no longer dispose of this matter by mere obstruction. In his message of December 5, I905, President Roosevelt briefly but forcefully called for legislation on the subject of misbranding and adulterating foods, drinks and drugs. In the same month Senator Heyburn re-introduced his bill, Senate bill No. 88, "for preventing the manufacture, sale, or transportation of adulterated or misbranded or poisonous or deleterious foods, drugs, medicine, and liquors, and for regulating traffic therein, and for other purposes."

On January 10, rgo6, he got the bill up for consideration. In his speech he pointed out the new features of this bill. In the first place, it held the officers of a corporation personally responsible for offenses, and in the second place, it separated liquors from food. Heyburn then proceeded to discuss the difficulty in which the states found themselves. "There are a number of fraudulent articles that are under the ban of this legislation, not a pound or ounce of which is offered for sale in the state in which it is manufactured, because they are provided against by the legislation of that state; but they are manufactured in one state and sent to another in unbroken packages under the rule of law that is now established, perhaps forever. So that the state into which they are sent is helpless against a flood of these impure articles sent in unbroken packages under the protection of that rule of law and then offered for sale upon the retail market." 28 In some states, he went on to say, sixty per cent of the drugs were adulterated, and Congress must meet the states half way. Heyburn later (February 2I) had a resolution and a report read from the American Medical Association which endorsed the Heyburn bill. It claimed to represent the conviction of 135,000 physicians in 2000 counties. 28

McCumber said the public and the press demanded action. "A great number of the leading magazines" were devoting considerable attention to the contents of this bill, and all the honest manufacturers were for it. $\mathrm{He}$, then, proceeded to explain from what sources the opposition came. The whiskey blenders, who were organized in the National Association of Liquor Dealers, had boasted that they alone had prevented the Senate from acting on this bill in the last two Congresses. Then there were the wine merchants and those merchants who sold cotton-seed oil for French olive oil. Besides these, there were some manufacturers of jellies. These were practically the only opponents of the bill, he said. ${ }^{30}$ But he should have inclucled the patent medicine fraternity. This he later did, and stated that it was perhaps true that ninety-five per cent of patent medicines were frauds and that ninety-five per cent of the drugs sold were patent medicines or proprietary medicines. ${ }^{31}$ The annual value of adulterated food, he estimated at three billion dollars. ${ }^{32}$

Senator Aldrich, the Republican leader in the Senate and an old enemy of pure food legislation, found himself obliged to fight in the open this time, a thing he

${ }^{28} 40$ CoNG. REc. 894-5 (I906).

${ }^{\infty} \mathrm{Id}$. at 2748 .

${ }^{20} I d$. at 1216-1218.

${ }^{31} I d$. at $266 \mathrm{r}-5$.

${ }^{22} \mathrm{Id}$. at $14 \mathrm{1} 4$. 
rarely did. Early in the debate he made a one-minute speech in which he tried to make the measure seem ridiculous by raising the question as to whether the time had come when Congress should prescribe for the people of the United States what they should eat and drink. To this McCumber replied, in effect, that the contrary was the truth, that this bill was intended to make it possible for everybody to buy the kind of food he wanted to eat:

Senator Money of Mississippi offered a substitute for S. 88. His bill had been drafted by the secretary of the National Food Manufacturers' Association and had the approval of three hundred food manufacturers. ${ }^{33}$ McCumber pointed out that the substitute bill would interfere with state pure-food laws, would be very difficult of enforcement, gave the manufacturers undue protection and advantages, and did not cover the patent medicines. ${ }^{34}$

The two Senators who bore the brunt of the fight for the bill were Heyburn, who was in charge, and McCumber. Among those who raised objections were Aldrich, Money, Bailey, Foraker, Spooner, Gallinger, Hemenway, Lodge, and Penrose. The vote in the Senate was taken on February 2I, Ig06, and passed by 63 to 4 , not voting 22. The four voting against the bill were Bacon of Georgia, Bailey of Texas, Foster of Louisiana, and Tillman of South Carolina. All four objected to the bill on constitutional grounds. Bailey insisted that the bill was "purely and only an exercise of the police power, and therefore not within the power of the federal government."35

Four months elapsed before the House of Representatives gave the bill its serious attention. Then it gave parts of three days-June 21, 22, 23-to its discussion. Hepburn of Iowa was in charge of the bill, but Mann of Illinois opened the debate. He stated that the delay had been due to appropriation bills, and that the leaders of the House had constantly assured the proponents of pure food legislation that this measure would be taken up. He said that after S. 88 had been referred to the House Committee on Interstate and Foreign Commerce, this committee struck out everything after the enacting clause and substituted for it the House bill. He explained the differences between the two bills, which were not important, except that the House bill provided for the fixing of food standards and that it had a provision on narcotics, which S. 88 did not have. He showed that many people had been misinformed as to the difference between the two bills. They had been led to believe that it was the Senate bill which dealt with narcotics, and so they demanded that the Senate bill be passed. ${ }^{36} \mathrm{He}$ intimated that it was the Proprietary Association which had inspired this impression.

A long minority report was submitted by members of the committee, signed by Adamson and Bartlett of Georgia and Russell of Texas. The whole contention of the minority report was that the federal government had no right to extend its police
${ }^{23}$ Id. at 2652-8.
${ }^{35} \mathrm{Id}$. at 2760 .
${ }^{34}$ Id. at $266 \mathrm{I}-5$.
${ }^{35}$ Id. at $8889-8900,9735-9740$. 
powers into the states. ${ }^{37}$ This was also the import of the speech which Adamson, as leader of the opposition, made on this occasion. "The truth about it is," he claimed, "the bill from first to last, violates every principle of our government by proposing to go into sumptuary legislation for the regulation of the table menu, and I suppose the next step will be to prescribe the table etiquette and dress." Applause greeted him when he said, "I believe there are millions of old women, white and black, all over my country, who know more about victuals and good eating than my friend Doctor Wiley and all of his apothecary shop."38

After a lively, though not acrimonious, debate in which there were frequent allusions to Wiley, Adams, and the excitement of the public, the House passed its own bill with a vote of $24 \mathrm{I}$ against $\mathrm{I7}$. In the ensuing conference committee Heyburn, McCumber, and Latimer represented the Senate, and Hepburn, Mann, and Ryan, the House. All the important features of the Senate bill were retained, and the provision on narcotics was added. The House clause for the creation of food standards was eliminated. ${ }^{30}$ In this form both houses agreed to the conference report on June 29, Ig06. The next day it received the President's signature.40

Before the House took up the consideration of the Hepburn bill, the Senate had started another important food measure.

For some time the meat industry had been under attack. In February, rgo6 The Jungle was published. Senator Beveridge of Indiana read it in March and called it to the attention of Roosevelt, not knowing that the latter had seen it in manuscript. ${ }^{41}$ Roosevelt was especially impressed with the reflections it cast on the government inspection service. He called Secretary Wilson's attention to it, who sent three men from the Department of Agriculture to Chicago to make an investigation. Conscious of the public excitement that had been aroused and fearing that the investigation by the agricultural department would result in a "whitewashing" report, Roosevelt sent a commission of his own to bring in a report. His investigators were James Bronson Reynolds, a reformer, and Charles P. Neill, a United States labor commissioner.

Unconscious of this investigation, Beveridge informed the President that he was

st. at 8gro-89r5.

${ }^{28} I d$. at $8955-6$.

* The absence of such standards embarrassed the administration of the Act, and it is intcresting to note that when, in 1930, the McNary-Mapes Bill was introduced to empower the Secretary of Agriculture to establish standards for canned products other than meat and milk, it passed both houses after brief discussion and without any serious opposition. Senator McNary said during the discussion that "the bill now receiving the attention of the Senate passed the House without any opposition. It is a bill proposed by the Department of Agriculture, has the approval of the canners throughout the country and of the Consumers' League, and I know of no opposition to it, aside from that of those who desire not to be exposed in their canning of inferior vegetables. The bill would simply permit the Secretary of Agriculture to formulate a grade for canned goods, so that if in the canning process such goods shall fall bclow that grade, they would have to be so branded." 75 Cong. Rec. ror64 (1930).

${ }^{40} \mathrm{Dr}$. Wiley felt that Roosevelt had been given undue credit for his efforts in behalf of the Food and Drugs Act. WiLEY, op. cit. supra note 1 , at 23r. Mann, while explaining the conference report to the House on June 29th, claimed that Representative Hepburn of Iowa was "principally entitled to the credit for the enactment of a pure-food law" (a statement which might be challenged).

4 40 CoNG. Rec. 9735-9740 (rgo6). 
drafting a meat inspection bill. The latter advised him to wait until Reynolds and Neill came back. On their return he consulted with them and continued working on his bill, drafting it about twenty times and sending every third or fourth draft to Wilson for comment.42 On May 25 he offered it as an amendment to the Agricultural Appropriation Bill, and it was adopted without debate or reference.

The amendment provided that the Secretary of Agriculture should cause postmortem examinations to be made of slaughtered cattle, sheep, swine, and goats; food products should be inspected; slaughtering and canning establishments should be kept in a sanitary condition; animals should be inspected before slaughtering; canned meat should bear the date of inspection on the label; inspections should be made also during the night; a fee should be charged for this service; animals for export should be inspected; labels on canned goods must not be falsified; but the act should not apply to farmers who might engage in local commerce.

The packers became frantic and tried to hush things up quickly. They inspired more than a thousand telegrams to Roosevelt, protesting against the publication of the Neill-Reynolds report; they induced the live-stock raisers of the country to support them; and they tried to intimidate the President and his commissioners. ${ }^{43}$ At the same time they began a feverish clean-up of the packing houses. ${ }^{44}$

When the bill came to the House, it was referred to the Committee on Agriculture. Here efforts were made to emasculate the meat inspection amendment. Chairman James W. Wadsworth of the committee was friendly to the packers, and in the hearings which he conducted he seemed to favor the meat industry. But Roosevelt was determined that the teeth should not be pulled out of the bill. He had received the Neill-Reynolds report on June 2, and two days later he sent an urgent message to the House, advocating the acceptance of the Beveridge amendment, and at the same time he sent the first part of the much-feared report, which was immediately broadcast by the press. This compelled favorable action on the part of the committee. When the bill was reported to the House on June ig the teeth had all been restored except two. It did not provide for the date on the label, but it did provide that $\$ 3,000,000$ be permanently appropriated for meat inspection, thus relieving the meat industry of that expense. In that form the bill was passed by a large vote, although not without severe criticism.

By this time the packers had changed their attitude. 'Thomas E. Wilson, one of the large Chicago packers, testified before the committee that the sale of meat and meat products had been more than cut in two, and another packer stated that every country in Europe had taken up the agitation and that it was hurting American business. They began to realize that government inspection was the only thing that could save their business, for that alone could restore the confidence of the public;

\footnotetext{
2 Bowers, Beverudge and the Progressive Era (1932) 228.

${ }^{4} I d$. at 229.

"Sullivan, op. cit. supra note 7, at 533-540.
} 
so they faced about and supported inspection. But they did not want to bear the cost of inspection, nor did they want the date on the label.

When the House message came before the Senate on June 20, it provoked both disappointment and satisfaction. Beveridge claimed the House bill was a much better one than any informed man had any right to expect during that session. ${ }^{45}$ Lodge used strong language on this occasion. He said "those packers in Chicago and those owners of the Standard Oil have done more to advance socialism and anarchism and unrest and agitation than all the socialistic agitators who stand today between the oceans." He wanted "that group of men" to be put on a level with other Americans. ${ }^{48}$ McCumber felt sure that the packers would shift the inspection fee to somebody else, because it was absolutely within their power to determine what they should pay for the live-stock and what they should charge the consumer of the meat. ${ }^{47}$ Warren of Wyoming, "the greatest shepherd since Abraham," was almost the only Senator who argued for the House measure. That, he said, had the support of the House of Representatives, of the Speaker, of the President, and of many Senators. Why should it not be a Roosevelt-Beveridge-Cannon-Wadsworth act? ?8 $^{4}$

Most of the Senators who expressed themselves urged their conferees to insist on the two points in question. On June 23 the conferees were appointed and consisted of Proctor of Vermont, Hansbrough of North Dakota, and Simmons of North Carolina. The House conferees were Wadsworth of New York, Scott of Kansas, and Lamb of Virginia.

Four days later Proctor reported to the Senate that the House conferees positively refused to compromise on the matter of paying for meat inspection. The Senate conferees had proposed a compromise to the effect that the packers should pay into the treasury five cents per head for cattle and three cents for every hog, sheep, and goat that was inspected. (This, it was estimated, would pay about half the actual expense.) But the suggestion had not been accepted. ${ }^{49}$ The other controversial point had not been touched upon.

The next day Proctor submitted the conference report on the Agricultural Appropriation Bill. Everything had been agreed upon except the points relating to meat inspection. ${ }^{50}$ The Senators urged their conferees not to jeopardize the whole bill on account of those two points, especially since they were not of fundamental importance.

On the same day the question was taken up in the House. Wadsworth moved that the House conferees should not recede from their position. This provoked a lively debate. Over and over it was stated (in both houses) that the packers had brought about the unsanitary conditions in the meat industry and that they should pay for correcting them. Humphrey of Washington delivered himself of the follow-

\footnotetext{
${ }^{4} I d$. at 542 .

40 Cong. Rec. 8763, 9656 (Igo6).

"Id. at 8767-9.

${ }^{45} I d$. at 8789 .

${ }^{10} \mathrm{Id}$. at gorg.

${ }^{\infty 0} \mathrm{Id}$. at $9076-8$.
} 
ing philippic: "The most loathsome and slimy criminal that curses the earth is the one that adulterates food." $\mathrm{He}$ is a "fiendish monster." "If I could call from the 'lowest depths of hell words so hot that I could construct out of them sentences that would writhe and hiss like the fanged and poisonous serpent,' I could not express my horror, my loathing, and my hate for those merciless fiends who, for the dollar, traffic in human health and human life, who poison and destroy and murder the helpless and unsuspecting victims that they have already robbed. . . . Honesty and decency stand stupified before the effrontery of the demands of these criminalsthat the people pay the cost of the inspection. What is their proposition? That the people shall pay to have them stop their filthy and dangerous practices; that the people shall pay to compel them to obey the law; that the people shall pay to stop them from defrauding and robbing the public; that the people shall pay to prevent them from destroying life and spreading disease; that the people shall pay to stop them from poisoning and murdering the innocent and helplessl A proposition more monstrous never came from the polluted lips of crime." 11 Nevertheless, the motion carried by a vote of 193 to 45 .

On June 29 the Senate gave way and the conference report was adopted by both houses. In the Senate there was considerable bitterness. Proctor said he had never seen "such open and bare-faced use" of the method of trying to influence Congress by flooding it with telegrams from all over the West, in identical language, "all evidently emanating from Chicago." N2 Nelson claimed that three things had been sought: (I) to placate the packers; (2) to placate the range-cattle men; (3) to get a good market for packers abroad. "I feel," he said, "as though when I go home I will go home like a licked dog, whipped by the packers and by the raisers of range cattle, and nobody else." ${ }^{33}$ McCumber thought the whole great conflict could be epitomized in a few words: "We have met the enemy and we are theirs-indemnity, $\$ 3,000,000$."54

On the same day that the pure food and drugs bill was signed, June 30 , 1906 , the agricultural appropriation bill, of which the meat inspection rider was a part, received the presidential signature. ${ }^{.5}$ The former went into effect on January $\mathrm{r}, \mathrm{I90}$, the latter, on July I, Ig06; and a struggle which for many years had been waged in the legislative arena was transferred to the field of administrative action. ${ }^{56}$

"Id. at 9470-2.

Id. at 9573 .

Id. at 9656 .

Id. at 9658 .

ss. at 9660 .

"It might be added that there had been a very decided decrease in the adulteration of food before June, 1906, because of the vigorous enforcement of the state pure-food laws. 